\title{
Function Analysis of the Enterprise Skills Training Center in the Engineering Education Field
}

\author{
Guihua Lin \\ Grid maintenance training department \\ State Grid of China Technology College \\ Jinan, China \\ e-mail: gh_lin@yahoo.cn
}

\author{
Tao Wang \\ Grid maintenance training department \\ State Grid of China Technology College \\ Jinan, China \\ e-mail: wangtaogongzuo@126.com
}

\begin{abstract}
The excellent engineer education and cultivation program carried out by the Ministry of Education aims to cultivate a large number of superior technical talents of superb innovation ability and of high adaptability to the needs of economic and social development. Especially in the program "full-time professional master" launched in 2009, the cultivation of superior talents of engineering research ability and application ability was highly accentuated. This essay, aiming at some problems existing in the current engineering education field and based on the engineering education cooperation and practice of substation secondary equipment maintenance of State Grid of China Technology College -State Grid Corporation of China skills training centre and Shandong university, explores the function of enterprise skills training center in the engineering education and the combination model of production, study and research. Moreover, this essay brings forward the feasible scheme for the next cooperation mode in the combination model of production and research of universities and enterprise skills training center and the engineering education development mode.
\end{abstract}

Keywords-engineering education; production, study and research combination; state-owned enterprise skills training center.

\section{INTRODUCTION}

In response to the significant strategic plan of the Chinese Party Central Committee and State Council's taking the new road of industrialization with Chinese characteristics and building a stronger country with talented people, the Ministry of Education puts forward the excellent engineer education and cultivation program to develop a great number of high-quality talents and various types of technical talents with superb innovation ability and high adaptability to the needs of economic and social development so as to serve the strategy of taking the new road of industrialization, and establishing an innovative country and a country with talented people. By 2010, China's undergraduate students of higher engineering education on campus have reached 3,710,000, and graduate students 470,000. Excellent engineer education and cultivation program plays a significant demonstration and guidance role in promoting the higher education to cultivate students in accordance with the social needs and in comprehensively improving the training quality of engineering education personnel.

Only academic master had been cultivated for engineering master's degree before 2009, but at the same time, most of the engineering masters had chosen to obtain employments after graduation. As a result of the academic education, the employers generally reflected that academic masters were relatively poor in professional skills. In this context, the Ministry of Education launched a "full - time professional master" as a new graduate situation [1]. From 2010, the number of academic masters has been reduced, and the number reduced has been used to increase the number of full-time professional masters to finally reach the ratio professional: academic=7:3. The professional master education puts more emphasis on cultivating senior talents of engineering study ability and application ability.

Judging from the present implementation of the excellent engineer education and cultivation program and the training process of the full-time professional master, there are still such problems as follows existing in China's current engineering education:

1. For students on campus, neither undergraduates nor full-time engineering masters have a sufficient knowledge of their own professional needs. They lack an understanding of what kind of knowledge is required for their future jobs and what kind of skills to grasp. Worse still, they are not targeted in their study.

2. Not only practices but also engineering training is insufficient in the engineering education process [2]. Both the equipments and instruments for the on-site use are relatively expensive. As a result of the financial factors, colleges and universities suffer from a lack of enough equipment to meet the demands of an increasing number of students. Consequently, engineering training is often more of a formality.

3. There are always inconsistencies between the direction in which our engineering education tries to cultivate students and the enterprise technique requirements $[1,4]$. Generally speaking, professional theoretical knowledge tends to be taught in the university and college education, while the knowledge of technical innovation and technical reform measures that are practically needed in the enterprises is insufficient. As a result, students cannot combine their theoretical knowledge with the specific job. And this results in a longer personal growth cycle.

4. The combination model of production, study and research waits for further exploration and development[5]. The enthusiasm for the state-owned enterprise to cooperate with universities and colleges in the technological research and development is increasing, while it is not sufficient in 
their joint training of the students. How to further arouse their enthusiasm remains a pending issue.

\section{TEXT}

This essay, taking electrical engineering as an example, combines the engineering education cooperation and practice of State Grid of China technology college substation secondary equipment maintenance-State Grid Corporation of China skills training centre and Shandong university and explores the function of enterprise skills training center in the engineering education and the combination model of production and research.

State Grid of China Technology College, being the enterprise vocational training institute directly under the control of State Grid Corporation, is a high-quality application and technical personnel and skilled personnel training base and the grid new techniques and skills application and demonstration center. It is established by the State Grid Corporation to vigorously change the development mode of the grid and enterprise, and to accelerate the construction of "one strength and three excellences"modern corporation. The college mainly centers on the training of the internal profession and production technology personnel. It is mainly responsible for such tasks as new employee training, training of technical personnel belonging to the provincial grid company headquarters and electric power research institute and scientific research units directly controlled by the company, technical personnel training of UHV, smart grid and new resources, system senior technician training of the company, international cooperation training, and the cultivation of innovative and technical skill personnel and so on; Moreover, the college progressively develops international cooperative running of schools and vocational technical education to strengthen the cultivation of high-level and practical talents, disseminate corporate culture, precipitate, manage and develop internal enterprise knowledge, and to enhance the enterprise's core competitiveness.

Substation secondary equipment maintenance of State Grid of China Technology College make new recruits of the Substation secondary equipment maintenance of State Grid Corporation of China, young technology leaders in support, and senior technical personnel its training objects. Through three to four months' training, new recruits can have a general knowledge of the values of the corporation, understand and accept the management idea and code of conduct of the corporation to cultivate their teamwork spirit; Cultivate the sense of working safety through learning safety production rules and regulations and working procedure, and grasping such basic skills as first aid measures for electric shock and health rescue; Exercise practical operation skills through getting familiar with job responsibilities, tasks and goals of substation secondary equipment maintenance, grasping the essentials of the job and working methods.

To meet the above training requirements, the substation secondary equipment maintenance establishes relay protection and electric automation center. There are such training rooms established as two $500 \mathrm{KV}$ relay protection training room, two $220 \mathrm{KV}$ relay protection training room, one $110 \mathrm{KV}$ relay protection training room, one CT characteristic test training room to satisfy 300 students' training at the same time. There is another UHV AC training room under construction. All devices are substation secondary equipments which are widely adopted by the current grid and which are representative. They include transformer protection, line protection, bus differential protection, circuit break protection, integrated substation automation devices, DC system, monitoring and control devices, and fault recorder. There are also secondary circuit fault simulator device, simulation circuit breaker and lock device, and substation primary system simulation screen. By these devices, the training of such substation secondary maintenance jobs as relay protection, integrated substation automation and DC maintenance and so on and the training and teaching of the related professions can be realized.

The main functions of State Grid of China Technology College in new recruits training mainly include the following two points:

1. Through training, a transition from students to corporation staff members will be realized. Moreover, besides shifting students' way of thinking, dissemination of the corporation culture can also be strengthened, and corporation identity of the students can also be increased so that students can rapidly integrate into the corporation.

2. Through training, technology and skills required by the production line jobs of State Grid Corporation can be mastered by students. Same equipments as the worksite will be used to teach students professional knowledge and operation skills required by the actual jobs so that they can return to their actual work after training. In this way, the growth cycle of students will be shortened.

It can be seen from the above two functions that State Grid of China Technology College is an indispensable link between the electrical engineering field, universities and State Grid Corporation. State Grid of China Technology College plays a critical role in accelerating the growth of graduates from colleges and universities in both thinking and skill. At the same time, on one hand, for State Grid of China Technology College, the research ability and theoretical knowledge of university and college teachers are worth learning and using for reference. On the other hand, the production skills of State Grid of China Technology College are urgently required by the university engineering education. Therefore, there is possibility and feasibility for the enterprise skill training center like State Grid of China Technology College to play an important role in the engineering education field.

In addition, as mentioned in the above preface, there is a lack of enthusiasm in the joint training of students for the enterprise. State Grid Corporation of China provides electricity transmission and supply to the country's 26 provinces, autonomous regions and municipalities directly under the central government, covering an area of more than $88 \%$ of China. The responsibility for security is extremely heavy. From the point of safety, there is almost no possibility for students on campus who have neither production knowledge nor operation skills to go to the first line substation to participate in the engineering training. In this 
context, State Grid of China Technology College, as the training institute which especially cultivates production skills, plays a critical role in the engineering education for the electric engineering besides completing normal training tasks. The latter one becomes an important breakthrough for the university electrical engineering to cultivate engineering technology talents.

The author here has been engaged in the substation secondary equipment maintenance training in State Grid of China Technology College for a long period. During the training process, the author has close relations with Shandong University. The two parties have conducted many cooperation and exchange activities. The author now concludes the following four points on how to promote the engineering education:

1. Exchanging teachers for teaching: The substation secondary equipment maintenance work requires of a profound storage of theoretical knowledge. By inviting teachers of Shandong University to teach in State Grid of China Technology College, trainees' theoretical knowledge can be enhanced, and at the same time, research developments can also be brought to the trainees so that they can grasp the latest technological developments; By inviting trainers of State Grid of China Technology College to teach in Shandong University, the following aspects of knowledge including production, work scope, work procedures, safety measures, and operation skills of the actual production site of the electric power system can be taught to students on campus. Students can acquire perceptual knowledge of the actual work of the electric power system, which not only promotes students' combining theoretical knowledge learned with the first line working environment but also helps them develop a systematic, comprehensive and rational understanding.

2. Strengthening exchange through research projects cooperation: The author here undertakes the key scientific and technological project of State Grid Corporation of China. (Serial Number SGKJ [2011]01) with Shandong University and tester manufacturer-Ponovo Power Co.,Ltd as the cooperation units. It is a simulation system development project for substation secondary equipment and its corresponding maintenance method. It is different from the conventional research and development project in that it is a collection of strengths from universities, corporations and equipment manufacturers. In this project, the research and development ability of universities, manufacturing technique of the corporations, and technical support of tester manufacturers were integrated well. Through cooperation, teachers of universities who participated in this project also grasped all the techniques, terms of agreement, design standard and operation and maintenance skills while doing research. Moreover, they connected their theoretical knowledge with the engineering practice, which not only improved their personnel level but also exercised the faculty. University teachers who have accepted research and development exercises in the research and development project which aims at engineering practices can teach the engineering knowledge they grasped to students on campus, which can greatly improve the level of engineering education.
3. Combine production, study and research together, cultivate full-time engineering masters jointly, and guide the graduation design of undergraduates. In addition to learning from each other and offset our own weakness through research projects, substation secondary maintenance staff members of State Grid of China Technology College and the electrical engineering college of Shandong University, on the occasion of project development, carries out further cooperation and exploration in engineering education such as adopting the combination model of production, study and research, cultivating full-time engineering masters and bachelors jointly, selecting excellent students from master degree candidates of electrical engineering college of Shandong University for a joint cultivation, selecting students to study theoretical knowledge of the electric power system at Shandong University, participating in the practical engineering training in the substation secondary maintenance training room in State Grid of China Technology College at regular intervals, combining theoretical knowledge with the practical engineering skills, comprehensively considering theory and engineering skill knowledge at the time of studying subjects or selecting subjects for the graduation design, selecting subjects that are not only of practical engineering significance but also of scientific research development significance to strive to cultivate high-quality electric power engineering technology talents of superior creativity and of high adaptability to the development of electric utility.

4. Organize university and college students to attend the training courses designed for the new recruits of State Grid Corporation of China to increase students' field experience and master practical work skills. There are two phases of training set every year in the substation secondary maintenance training of State Grid of China Technology College, and six classes are set for each phase. What is trained is work skills related to substation secondary maintenance group of State Grid Corporation of China. Students of universities and colleges can attend to the training courses of new recruits through application to enhance their own engineering skill knowledge.

It can be predicted from the above engineering education practice of combining production, study and research together that state-owned skill training center will play a more and more important role in the engineering education field in future. As indicated in Figure 1, universities and enterprise training centers can improve the level of their own faculty interactively by the way of science and technology project research and development and exchange of teaching; students of universities and colleges can attend to the courses of enterprise training center. At the same time, it is imagined in this essay that pre-job skills training should be done in advance to students of collaborating enterprises, and that graduation thesis should be guided jointly: take the intersection part of the three groups-universities, enterprise training center and university students for an example, State Grid Corporation of China will do tour recruitments in various universities before the annual Spring Festival, and will basically finish all the recruitment plans in the next March. March is a month when undergraduates choose 
subjects for their graduation designs, and master degree candidates write their graduation thesis, and a month when students who have signed contracts with enterprises become staff members of the enterprise. It is a connecting point of the last phase of student time and working career. Students' growth in this month plays a critical role in their future work. During this time, the enterprise training center can organize contracted students to attend to the pre-job induction training in advance, and through three months' skill training, students can master the basic position skills of future work. At the same time, undergraduates who have attended to the training in advance can write the thesis with skill knowledge learned during the training and full-time engineering masters can further closely relate the research subjects during master period to the training content so as to achieve excellent master thesis that meets the requirements of the engineering development. Students after training will return to campus for the graduation thesis defense. Under this model, enterprises can shorten the cultivation time of new recruits, students can acquire enough engineering practice, universities and colleges can deepen their relationships with enterprises, and production, study and research will be combined more closely. All these achievements will gain a three-win situation for the enterprises, universities and students, which will lay a profound foundation for cultivating advanced talents of high engineering research ability and creativity, taking the new road of industrialization development, building an innovation-oriented country and implementing the strategy of building a stronger country with talented people.

\section{CONCLUSIONS}

Enterprises nowadays attach more and more importance to the vocational skills training, especially those large state- owned enterprises like State Grid Corporation of China. The scale of the especially established skill training center is becoming larger and larger, which plays a critical role in improving the enterprise staff members' technology and skill level. Set connecting points between training new recruits and universities, and adopt appropriate combination model of production, study and research and a variety of cooperation methods so as to improve the engineering education level, enhance the university faculty, and cultivate more senior talents of high engineering research ability and application ability for our society and country.

\section{ACKNOWLEDGMENT}

The project is supported by the Key technology projects of State Grid Corporation(SGKJ2011-01).

\section{REFERENCES}

[1] Liu Xiaojuan and Zhao Yonggang. Cultivation and Research of Fulltime Engineering Masters of Professional Degree. (Journal of Ningxia University( Humanities \& Social Sciences Edition)[J].2011. Vol.33(5),pp.173-175.

[2] Yu Xiaoming. Reform of Engineering Education Methods and Cultivation Patterns. China Electric Power Education [J]. 2008 Vol.120,pp.152-153.

[3] Zhang Shifeng. Problems and Reflection of Engineering Master Cultivation [J]. Journal of Higher Education Research, 2008.Vol.1,pp.81-82.

[4] Li Huifang, Peng Bangguo and Huang Changxi. Rational Reflection on China Engineering Education Reform[J]. Media Education, 2011,pp.107-108.

[5] Shen Xiaoming. Focus on Engineering Practice Ability and Improve Engineering Education level. China Higher Educaiton. 2008. Vol.2,pp.38-40. 